Eur. J. Clin. Chem. Clin. Biochem.

Vol. 31, 1993, pp. 419-426

(C) 1993 Walter de Gruyter \& Co.

Berlin - New York

\title{
Human Pharmacokinetics of Orally Administered (24 R)-Hydroxycalcidiol
}

\author{
By O. R. Leeuwenkamp, H. E. van der Wiel, P. Lips, W. J. F. van der Vijgh, R. Barto, H. Greuter and \\ J. C. Netelenbos
}

Department of Internal Medicine, Free University Hospital, Amsterdam, The Netherlands

(Received April 21, 1992/April 4, 1993)

Summary: To gain an insight in the regulation of (24R)-hydroxycalcidiol, we studied the pharmacokinetics of orally administered (24R)-hydroxycalcidiol in 6 healthy subjects without calcium supplementation, in 4 healthy subjects with calcium supplementation and in 6 patients with primary hyperparathyroidism. Various quantities related to calcium and vitamin $\mathrm{D}$ metabolism were also monitored.

In the healthy subjects without calcium supplementation, the basal $(24 R)$-hydroxycalcidiol concentration $\left(C_{b}\right)$ in serum was $2.4 \pm 0.8 \mathrm{nmol} / \mathrm{l}$ (mean $\pm \mathrm{SD}, \mathrm{n}=5$ ), the terminal serum half-time $\left(\mathrm{t}_{1 / 2}\right) 7.2 \pm 1.4$ days, the production rate $0.05 \pm 0.01 \mathrm{nmol} / \mathrm{kg} \cdot$ day, and the production rate/[calcidiol] ratio $\left(1.5 \pm 0.4 \times 10^{-3} \mathrm{l} / \mathrm{kg}\right.$ - day). In the healthy subjects studied, the serum concentration vs time curves exhibited a second maximum after administration, possibly due to binding by intestinal cells or (partial) uptake by the lymph system. In the calcium-supplemented healthy subjects, the pharmacokinetic quantities were not significantly different while the area under the serum concentration-time curve and the estimated bioavailability were significantly decreased.

Basal concentration $\left(C_{b}\right)$, production rate and the production rate/[calcidiol] ratio were significantly lower in patients with primary hyperparathyroidism but $\mathrm{t}_{1 / 2}$ was unchanged.

Exogenous (24R)-hydroxycalcidiol had no clear effect on calcium and vitamin D metabolism.

In conclusion,

a) exogenous (24R)-hydroxycalcidiol has no clear effect on calcium and vitamin D metabolism,

b) clearance and production rate of (24R)-hydroxycalcidiol are not affected by calcium supplementation,

c) bioavailability is lower in the calcium-supplemented state,

d) basal concentration $\left(\mathrm{C}_{\mathrm{b}}\right)$ and production rate are significantly decreased in patients with hyperparathy-roidism.

\section{Introduction}

It is generally accepted that calcitriol $(1 \alpha, 25$-dihydroxycholecalciferol) represents the biologically active metabolite of vitamin $\mathrm{D}_{3}$ (1), while the function of (24R)-hydroxycalcidiol is still controversial. $\mathrm{Hu}-$ man pharmacokinetics of (24R)-hydroxycalcidiol have been studied $(2-5)$, but only one of these studies yielded reliable estimates for its clearance and pro- duction rate (5). In vitro and in vivo studies have demonstrated that the activity of rat 24-hydroxylase is modulated by parathyroid hormone (parathyrin) $(6-8)$, calcitriol $(7-11)$, dietary calcium $(7,10-13)$, and phosphorus $(7,10)$. Hence, production rate or clearance of $(24 R)$-hydroxycalcidiol may be determined by these factors and may reflect abnormalities of calcium and vitamin $D_{3}$ metabolism. 
To gain insight in the regulation of (24R)-hydroxycalcidiol in humans, we studied in detail the pharmacokinetics of orally administered (24R)-hydroxycalcidiol in

a) healthy subjects,

b) healthy subjects with calcium supplementation, and

c) patients with primary hyperparathyroidism.

\section{Experimental}

Design of the pharmacokinetic studies

After fasting since midnight, 6 healthy males $(31 \pm 5$ a) each received orally $100 \mu \mathrm{g}$ of $(24 R)$-hydroxycalcidiol. The plasma concentration of this metabolite was determined at $\mathrm{t}=-1$ and $0 \mathrm{~h}$ to obtain its basal serum concentration. (24R)-Hydroxycalcidiol was determined at 2, 3, 5 and $8 \mathrm{~h}$, and at day 1, 2, 3, $6,10,13$ and 21 after dosing. Calcidiol (25-hydroxycholecalciferol) and calcitriol (1 1,25 -dihydroxycholecalciferol) were also determined at these times. Serum calcium, phosphate, intact perathyroid hormone $(1-84)$, albumin, creatinine and vitamin D-binding protein were measured at 0 and $8 \mathrm{~h}$ and at day 1 , 10 and 21 . The study was performed in January and February.

Four healthy male subjects ( $37 \pm 9$ a) were supplemented for 42 days (January - February) with $1 \mathrm{~g}$ of calcium in the evening (Calcium Sandoz. fortissimum). After an equilibration period of 19 days, $100 \mu \mathrm{g}$ of (24R)-hydroxycalcidiol were orally administered in the fasting state. (24R)-Hydroxycalcidiol, calcidiol and calcitriol were determined on the day of administration (day 0 ) at $0,2,3,5$ and $8 \mathrm{~h}$. These metabolites were also determined on day $-19,-18,-5,-1,1,2,3,12,15$, and 21 . Serum $\mathrm{Ca}, \mathrm{P}_{\mathrm{i}}$ and parathyrin were measured on day -19 , -18 . $-5,0,1$ and 21 , and at day 0 , i.e. $10 \mathrm{~h}$ after dosing.

The design of the study for the patients with primary hyperparathyroidism has already been described in detail (14).

\section{Materials}

Non-labelled vitamin $D_{3}$ metabolites and capsules containing $25 \mu \mathrm{g}$ of (24R)-hydroxycalcidiol were a generous gift from Duphar (Weesp, The Netherlands). $\left[23,24-{ }^{3} \mathrm{H}\right](24 R)$-Hydroxycalcidiol, $\left[23,24-{ }^{3} \mathrm{H}\right]$ calcitriol and $\left[26,27\right.$ methyl $\left.-{ }^{3} \mathrm{H}\right]$ calcidiol were obtained from the Radiochemical Centre, Amersham, UK.

\section{Assays}

(24R)-Hydroxycalcidiol, calcidiol and calcitriol were determined as previously described in detail (15). The vitamin $D_{2}$ and vitamin $D_{3}$ metabolites were not separated by the chromatographic system used. Since food is not fortified with vitamin $D_{2}$ in The Netherlands, the circulating serum concentrations of the vitamin $D_{2}$ metabolites are negligible compared with the serum concentrations of their $D_{3}$ counterparts. The samples of each individual were run within one series, to eliminate interassay variations. Quality control samples were run with each analytical series. The intra-assay coefficients of variation were $9.3,3.0$ and $11.1 \%$, respectively. Intact parathyrin $(1-84)$ was determined by a two-step immunochemical method of Hackeng et al. (16), vitamin D binding protein was determined by radial immunodiffusion (17) and the other biochemical quantities were determined with standard procedures.

To investigate the specificity of our ( $24 R$ )-hydroxycalcidiol assay procedure, the remaining serum from non-supplemented healthy subjects $1-3$ collected at days $2,3,5$ and 7 , was pooled.
Aliquots of these pooled samples were chromatographed on the chromatographic system used in our assay procedure (15), the (24R)-hydroxycalcidiol fractions were collected, the eluent evaporated under a stream of nitrogen and the residue dissolved in $480 \mu \mathrm{l}$ of ethanol. Of this solution $350 \mu \mathrm{l}$ were used to determine (24R)-hydroxycalcidiol; $100 \mu$ l were rechromatographed on a $30-\mathrm{cm} \mathrm{C}_{18}$ column (Spherisorb ODS 2) with $95: 5$ methanol-water as eluent $(1.0 \mathrm{ml} / \mathrm{min})$, the $(24 R)$-hydroxycalcidiol fractions were collected (recovery $66 \%$, retention time $7 \mathrm{~min}$ ), and (24R)-hydroxycalcidiol was determined again.

\section{Pharmacokinetic analysis}

For the non-supplemented healthy subjects, the post-dosing serum concentrations of $(24 R)$-hydroxycalcidiol were corrected for the basal concentration $\left(C_{b}\right)$ of the metabolite by subtracting the mean of the pre-dosing serum concentrations at $t=-1$ and $0 \mathrm{~h}$, respectively.

The terminal serum half-time $\left(t_{1 / 2}\right)$ was calculated (day $5-21$ ) with a non-linear estimation program (PCNONLIN) (18). The area under the total plasma concentration vs time curve (AUC) was estimated by numerical integration (linear trapezoidal rule) (19). The systemic clearance $(\mathrm{Cl})$ was calculated by multiplying the serum elimination rate constant $\mathrm{k}\left(0.693 / \mathrm{t}_{1 / 2}\right)$ by the distribution volume $\left(V_{d}\right)(20) ; V_{d}$ was taken as $0.191 / \mathrm{kg}(5)$. The production rate was obtained from $\mathrm{C}_{b} \times \mathrm{Cl}$.

Production rate was normalized by expressing production rate (PR) per kg of body weight. Production of (24R)-hydroxycalcidiol follows Michaelis-Menten kinetics $\mathrm{PR}=\mathrm{PR}_{\max } \times[\mathrm{cal}-$ cidiol] $/\left(K_{\mathrm{m}}+\right.$ [calcidiol]) with a $K_{\mathrm{m}}$ of about $1 \mu \mathrm{mol} / 1(21-24)$, which means that $K_{\mathrm{m}} \gg$ [calcidiol] and $\mathrm{PR}=\mathrm{PR}_{\max } \times$ [calcidiol] $/ K_{\mathrm{m}}$. Because production rate depends linearly on [calcidiol], PR/[calcidiol] ratios were calculated. The PR/[calcidiol] ratio $\left(=\mathrm{PR}_{\max } / K_{\mathrm{m}}\right)$ is a measure of the 24 -hydroxylase activity. These ratios were also normalized for body weight.

In the calcium-supplemented subjects, the observed pre-dosing trend of (24R)-hydroxycalcidiol (see Results) was extrapolated to give the basal serum concentrations after dosing. After correction of the measured post-dosing values, the pharmacokinetic values were calculated as already outlined.

Previously we studied the pharmacokinetics of (24R)-hydroxycalcidiol in 18 patients with primary hyperparathyroidism (14). In 6 of these patients $(60 \pm 15 \mathrm{a})$, initial half-time $\left(t_{1 / 2.1}\right)$, postdosing half-time $\left(t_{1 / 2,1}\right)$, production rate (PR) and $P R /$ [calcidiol] ratio normalized for body weight were evaluated. $t_{1 / 2,1}$ was obtained after correction of the measured serum concentrations for the basal serum concentration at month 3 (fig. 3 ). $t_{1 / 2.1}$ was estimated from:

a) the AUC (month 3-5), applying $\mathrm{Cl}=\mathrm{F} \times \mathrm{D} / \mathrm{AUC}_{3->5}$ (20) and $\mathrm{Cl}=\left(0.693 / \mathrm{t}_{1 / 2,1}\right) \times \mathrm{V}_{\mathrm{d}}(20)$ and setting the bioavailability $(F)$ of orally administered $(24 R)$-hydroxycalcidiol to 0.7 (5); and

b) $r_{s s}=1-e^{-N k T}(25)$, where $r_{s s}$ represents the ratio of the serum concentration reached at month 4 to the (mean) steady-state serum concentration, $\mathrm{N}$ the number of dosages given up to month $4, \mathrm{k}$ the elimination rate constant $\left(\mathrm{t}_{1 / 2.1}=0.693 / \mathrm{k}\right)$ and $T$ the dosing interval ( 1 day). In the second method, the mean of the serum concentrations at month 5 and 6 was taken as the (mean) steady-state serum concentration. $t_{1 / 2,2}$ was obtained from the declining portion of the serum concentration vs time curve (fig. 3). To obtain the initial production rate $P R\left(P R_{1}\right)$ and the post-dosing production rate $\left(\mathrm{PR}_{2}\right)$, basal concentration at month $3\left(\mathrm{C}_{\mathrm{b}, 1}\right)$ and basal concentration at month $9\left(C_{b, 2}\right)$ (seeifig. 3) were used. Finally, $\mathrm{PR}$ and $\mathrm{PR} /[$ calcidiol] ratio were normalized for body weight. To obtain this ratio, the mean of calcidiol during month 3-5 was used. 


\section{Statistical analysis}

Significance levels werc obtained by applying Student's t-test. $\mathrm{P}<0.05$ was considered statistically significant.

\section{Results}

Rechromatography on the reversed phase chromatographic system used did not affect the determined concentrations of (24R)-hydroxycalcidiol, indicating that only (24R)-hydroxycalcidiol was determined in our assay procedure for (24R)-hydroxycalcidiol.

In the non-supplemented subjects, the serum concentration vs time curves of (24R)-hydroxycalcidiol exhibited a second maximum on day $2-3$ (fig. 1). Therefore, the terminal half-time was calculated from day $5-21$. The resulting pharmacokinetic data are summarized in tables 1 and 2 . The basal serum concentration of subject $3(P<0.01), P R(P<0.01)$ and

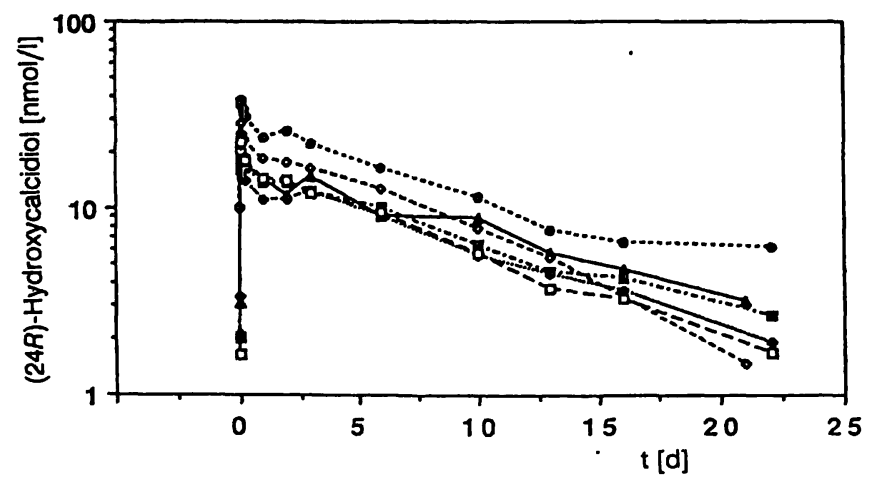

Fig. 1. Semilogarithmic plots of the serum concentration vs time curve after oral administration of $100 \mu \mathrm{g}$ of (24R)hydroxycalcidiol to the non-supplemented healthy subjects. Subject 1-6: $\Delta, \diamond, 0, \diamond, \square, \square$.

$\mathrm{PR} /[$ calcidiol] ratio $(\mathrm{P}<0.001)$ were significantly higher (tab. 1). Excluding this subject, the PR and $\mathrm{PR} /$ [calcidiol] ratio were $0.05 \pm 0.01 \mathrm{nmol} / \mathrm{kg} \cdot$ day and $1.5 \pm 0.4 \times 10^{-3} \mathrm{l} / \mathrm{kg} \cdot$ day (tab. 2), respectively.

Tab. 1. Pharmacokinetics of (24R)-hydroxycalcidiol after oral administration of $100 \mu \mathrm{g}$ to the non-supplemented healthy subjects.

\begin{tabular}{|c|c|c|c|c|c|c|}
\hline & $\begin{array}{l}\text { Basal serum } \\
\text { concentration } \\
(\mathrm{nmol} / \mathrm{l})\end{array}$ & $\begin{array}{l}\text { Maximum serum } \\
\text { concentration } \\
\left.(\mathrm{nmol} / \mathrm{l})^{\prime}\right)\end{array}$ & $\begin{array}{l}\text { Terminal } \\
\text { half-time }{ }^{2} \text { ) } \\
\text { (days) }\end{array}$ & $\begin{array}{l}\text { Systemic } \\
\text { clearance } \\
\text { (1/day) }\end{array}$ & $\begin{array}{l}\text { Production rate } \\
\text { (nmol/day) }\end{array}$ & $\begin{array}{l}\left.\mathrm{AUC}^{3}\right) \\
(\mathrm{nmol} \cdot \mathrm{h} / \mathrm{l})\end{array}$ \\
\hline $\begin{array}{l}1 \\
2 \\
4 \\
5 \\
6\end{array}$ & $\begin{array}{l}3.11 \\
3.35 \\
2.12 \\
2.02 \\
1.61\end{array}$ & $\begin{array}{l}21.93 \\
18.25 \\
28.59 \\
16.84 \\
22.47\end{array}$ & $\begin{array}{l}8.55 \\
7.22 \\
5.17 \\
8.46 \\
6.60\end{array}$ & $\begin{array}{l}1.01 \\
1.50 \\
1.84 \\
1.06 \\
1.38\end{array}$ & $\begin{array}{l}3.15 \\
5.02 \\
3.89 \\
2.14 \\
2.22\end{array}$ & $\begin{array}{l}3912 \\
3236 \\
4285 \\
3752 \\
3352\end{array}$ \\
\hline $\begin{array}{l}\text { Mean } \\
\text { SD }\end{array}$ & $\begin{array}{l}2.44 \\
0.75\end{array}$ & $\begin{array}{r}21.62 \\
4.57\end{array}$ & $\begin{array}{l}7.20 \\
1.40\end{array}$ & $\begin{array}{l}1.36 \\
0.34\end{array}$ & $\begin{array}{l}3.28 \\
1.21\end{array}$ & $\begin{array}{r}3707 \\
426\end{array}$ \\
\hline 3 & 10.06 & 37.90 & 7.08 & 1.40 & 14.08 & 5040 \\
\hline
\end{tabular}

1) Corrected for basal concentration $C_{b}$.

2) Calculated from day 5 because of the second maximum.

${ }^{3}$ ) Area under the total serum concentration vs time curve.

Tab. 2. Characterization of the healthy subjects from this study and l.c. (5) and the patients with primary hyperparathyroidism from 1.c. (14).

\begin{tabular}{|c|c|c|c|c|c|c|c|}
\hline \multirow[b]{4}{*}{ Body weight $(\mathrm{kg})$} & \multicolumn{3}{|c|}{ Healthy subjects } & \multirow{2}{*}{\multicolumn{4}{|c|}{$\begin{array}{l}\text { Primary hyperparathyroidism } \\
\text { Oral application } \\
(n=6)\end{array}$}} \\
\hline & \multicolumn{2}{|c|}{ Oral application } & \multirow[t]{2}{*}{$\begin{array}{l}\text { iv application } \\
(n=4)\end{array}$} & & & & \\
\hline & $\begin{array}{l}\text { Non- } \\
\text { supplemented } \\
(n=5)\end{array}$ & $\begin{array}{l}\text { Ca- } \\
\text { supplemented } \\
(n=4)\end{array}$ & & initial') & \multicolumn{3}{|c|}{ post-dosing') } \\
\hline & $71.4 \pm 6.3$ & $67.8 \pm 5.4$ & $67.8 \pm 5.4$ & $81.8 \pm 8.3$ & & - & \\
\hline Calcidiol $\left.(\mathrm{nmol} / \mathrm{l})^{2}\right)$ & $31.0 \pm 4.2$ & $44.3 \pm 13.5$ & $60.8 \pm 21.3$ & $25.5 \pm 9.4$ & $41.1 \pm$ & \pm 8 & 8.0 \\
\hline Calcitriol $\left.(\mathrm{pmol} / 1)^{2}\right)$ & $92.6 \pm 26.0$ & $89.5 \pm 12.6$ & $84.5 \pm 9.0$ & $206 \pm 65$ & $207 \pm$ & \pm 50 & \\
\hline Basal concentration (nmol/l) & $2.4 \pm 0.8$ & $3.5 \pm 1.4$ & $4.2 \pm 1.3$ & $0.5 \pm 0.5$ & $1.7 \pm$ & & 1.1 \\
\hline $\mathrm{t}_{1 / 2}$ (days) & $7.2 \pm 1.4$ & $9.7 \pm 2.0$ & $8.2 \pm 2.9$ & $7.2 \pm 1.8$ & $12.5 \pm$ & \pm 1 & 1.8 \\
\hline $\mathrm{PR}$ (nmol/kg $\cdot$ day) & $0.05 \pm 0.01$ & $0.04 \pm 0.01$ & $0.07 \pm 0.03$ & $0.01 \pm 0.01$ & $0.01 \pm$ & \pm 0 & 0.01 \\
\hline $\mathrm{PR} /[$ calcidiol $]\left(10^{-3} \times \mathrm{l} / \mathrm{kg} \cdot\right.$ day $)$ & $1.5 \pm 0.4$ & $1.1 \pm 0.4$ & $1.2 \pm 0.3$ & $0.2 \pm 0.2$ & $0.2 \pm$ & \pm 0 & 0.1 \\
\hline
\end{tabular}

') Initial values refer to month $3-5$ and post-dosing values to month $6-8$.

2) The values at the start of the study are given for the calcium-supplemented subjects. These values declined lincirly during the whole study period (see Results). 
In the calcium-supplemented subjects, the second maximum was seen earlier, i.e. 8-24 h after dosing. The peak plasma concentration $\left(C_{\max }\right)$ of $8.85 \mathrm{nmol} / 1$ and the area under the serum concentration vs time curve (AUC) of $2279 \mathrm{nmol} \cdot \mathrm{h} / \mathrm{l}$ were significantly lower $(\mathrm{P}<0.01)$, but the other pharmacokinetic quantities were unchanged (tab. 1). During the study period, serum calcitriol and calcidiol declined almost linearly from $89.5 \pm 12.6 \mathrm{pmol} / \mathrm{l}$ and $44.3 \pm 13.5$ $\mathrm{nmol} / \mathrm{l}$ to $77.8 \pm 17.4 \mathrm{pmol} / \mathrm{l}$ and $34.8 \pm 10.5 \mathrm{nmol} / \mathrm{l}$, respectively.

In the patients with primary hyperparathyroidism, the initial basal serum concentration of (24R)-hydroxycalcidiol, PR and PR/[calcidiol] ratio (tab. 2) were significantly lower $(P<0.001)$ than in the healthy non-supplemented subjects of this study $(\mathrm{n}=5)$. The initial half-time in these patients was comparable, but the post-dosing half-time was significantly increased $(\mathrm{P}<0.001)$ (tab. 2). At month 9, the serum concentrations of (24R)-hydroxycalcidiol and calcidiol were significantly higher than the pre-dosing values $(\mathrm{P}<0.02)$ (tab. 2).

The effect of exogenous (24R)-hydroxycalcidiol on the quantities of calcium and vitamin D metabolism was also studied. A short-term and transient increase of calcitriol was found, especially in subject 5 (tab. 3).

Strong positive correlations [(24R)-hydroxycalcidiol] vs [calcidiol]) were found (fig. 2) for

a) the 13 healthy subjects from this study and l.c. (5) and

b) the 18 patients with primary hyperparathyroidism from l.c. (14). The two subgroups of this study

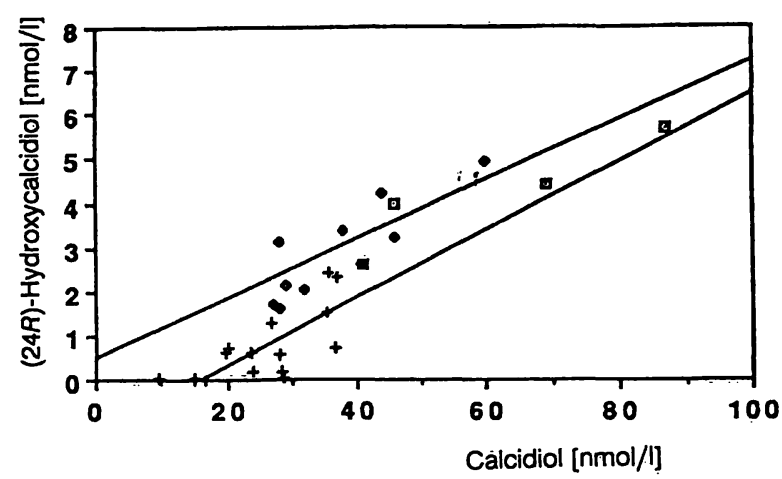

Fig. 2. Plots of the serum concentrations of (24R)-hydroxycalcidiol vs calcidiol.

Healthy subjects from this study ( $\diamond)$ and l.c. (5) (ם): $[(24 R)$-hydroxycalcidiol $]=0.063 \times$ [calcidiol $]+0.51$, $\mathrm{n}=13, \mathrm{r}=0.89, \mathrm{P}<0.0001$.

Patients with primary hyperparathyroidism from 1.c. (14) (+):

[(24R)-hydroxycalcidiol] $=0.074 \times$ [calcidiol] -1.14 , $\mathrm{n}=18, \mathrm{r}=0.76, \mathrm{P}<0.0005$.

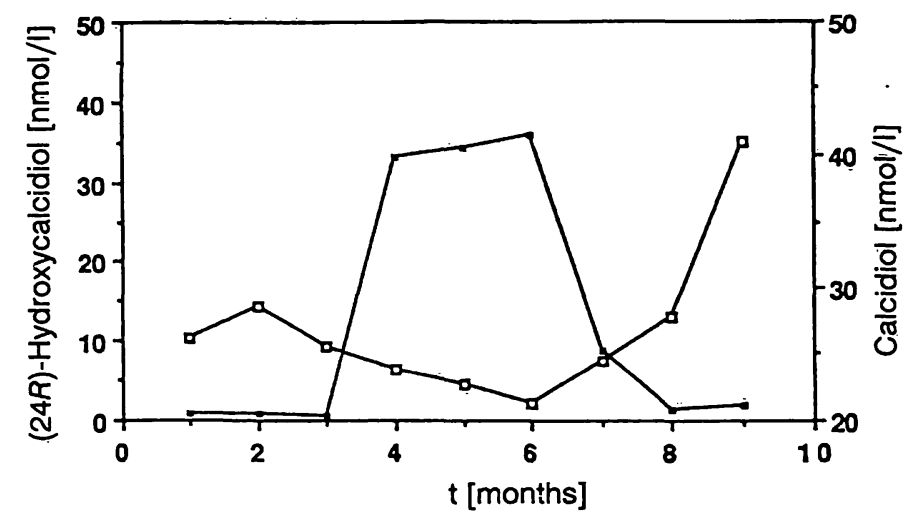

Fig. 3. Serum concentration vs time curves of $(24 R)$-hydroxycalcidiol (ם) and calcidiol ( $\square$ ) in 6 patients with primary hyperparathyroidism from l.c. (14), receiving daily $25 \mu \mathrm{g}$ of (24R)-hydroxycalcidiol during 3 months.

Tab. 3. The plasma concentrations of calcitriol and calcidiol after oral administration of $100 \mu \mathrm{g}$ of (24R)-hydroxycalcidiol to the non-supplemented healthy subjects.

\begin{tabular}{|c|c|c|c|c|c|c|c|c|c|c|c|c|}
\hline \multirow[b]{2}{*}{ Subject } & \multicolumn{6}{|c|}{$\begin{array}{l}\text { Calcitriol } \\
(\mathrm{pmol} / \mathrm{l})\end{array}$} & \multicolumn{6}{|c|}{$\begin{array}{l}\text { Calcidiol } \\
\text { (nmol/l) }\end{array}$} \\
\hline & 1 & 2 & 3 & 4 & 5 & 6 & 1 & 2 & 3 & 4 & 5 & 6 \\
\hline \multicolumn{13}{|l|}{$\begin{array}{l}\text { Time } \\
\text { (hours) }\end{array}$} \\
\hline 0 & 78 & 63 & 55 & 119 & 121 & 82 & 28 & 38 & 53 & 29 & 32 & 28 \\
\hline 2 & 86 & - & 64 & 134 & 135 & 82 & 26 & 36 & 56 & 32 & 33 & 27 \\
\hline 3 & 97 & - & 61 & 111 & 175 & 86 & 27 & 38 & 59 & 28 & 33 & 30 \\
\hline 5 & 105 & - & 70 & 134 & 192 & 107 & 29 & 36 & 61 & 29 & 36 & 27 \\
\hline 8 & 73 & 52 & 55 & - & 164 & 121 & 31 & 38 & 63 & - & 39 & 31 \\
\hline \multicolumn{13}{|l|}{ (days) } \\
\hline 1 & 95 & - & 80 & 112 & 131 & 110 & 30 & 38 & 55 & 29 & 34 & 30 \\
\hline 2 & 74 & - & 84 & 125 & 114 & 110 & 29 & 37 & 53 & 30 & 37 & 26 \\
\hline 3 & 45 & 49 & 53 & 102 & 100 & 168 & 30 & 36 & 52 & 30 & 35 & - \\
\hline 6 & 84 & - & 87 & 142 & 110 & 103 & 30 & 40 & 62 & 29 & 36 & 28 \\
\hline 10 & 75 & - & 38 & 144 & 163 & 112 & 31 & 41 & $74:$ & 31 & 36 & 27 \\
\hline 13 & 102 & - & 73 & 140 & 59 & 146 & 27 & 36 & 59 : & 29 & 39 & 29 \\
\hline 16 & 85 & - & 68 & 77 & 113 & 129 & 28 & 36 & 54 & 30 & 37 & - \\
\hline 21 & 89 & 69 & 78 & 112 & 97 & 129 & 32 & 36 & 62 & 34 & 38 & 25 \\
\hline
\end{tabular}


$(\mathrm{n}=9)$ and the healthy subjects from 1.c. (5) $(n=4)$ were taken together, because these groups were not statistically different with regard to the plasma concentrations of calcidiol and (24R)-hydroxycalcidiol.

None of the biochemical conditions studied was affected by exogenous (24R)-hydroxycalcidiol.

\section{Discussion}

The terminal half-time $\left(\mathrm{t}_{1 / 2}\right)$ and the systemic clearance (Cl) of (24R)-hydroxycalcidiol in the non-supplemented healthy subjects after oral administration are comparable to the values found by our group (5) for intravenously administered (24R)-hydroxycalcidiol. Kanis et al. (3) found half-times of 9 and 34 days after iv administration of $100 \mu \mathrm{g}$ of (24R)-hydroxycalcidiol to two healthy subjects. The much shorter half-times found by Kumar et al. (4) most probably represent the distribution half-times, because collection of the blood samples was limited to $6 \mathrm{~h}$ after administration of (24R)-hydroxycalcidiol. On the other hand, these authors (4) observed that after administration of tritiated (24R)-hydroxycalcidiol about $60 \%$ of the radioactivity was excreted in faeces and urine up to day 7 , suggesting a half-time of 5.3 days, which is comparable to the half-time found in the present study.

In contrast to the plasma concentration vs time curves of intravenously administered (24R)-hydroxycalcidiol (5), the plasma concentration vs time curves after oral administration of (24R)-hydroxycalcidiol exhibited a second maximum (day $2-3$ ) in 3 subjects (fig. 1). In principle, this maximum might be due to:

a) formation of a metabilite of (24R)-hydroxycalcidiol with a higher affinity than (24R)-hydroxycalcidiol for the vitamin $\mathrm{D}$ binding protein present in the rat plasma used for the assay of (24R)-hydroxycalcidiol;

b) enterohepatic cycling of (24R)-hydroxycalcidiol;

c) binding of (24R)-hydroxycalcidiol in intestinal cells $(26,27)$ followed by a slow concentrationdependent release into the circulation;

d) (partial) uptake of (24R)-hydroxycalcidiol, like vitamin $\mathrm{D}_{3}$ (28) and calcidiol (29), via the lymph system and subsequent (slow) release into plasma; and

e) rectal absorption. Since a second maximum was not observed after iv administration of (24R)-hydroxycalcidiol (5), this maximum might be due to a metabolite which is produced exclusively in in- testinal tissue and also coassayed in our assay procedure for (24R)-hydroxycalcidiol. Because rechromatography in a second chromatographic system did not affect the determined concentrations of (24R)-hydroxycalcidiol, formation of such a metabolite is not likely. This finding is consistent with the observation that the terminal half-times for iv and oral (24R)-hydroxycalcidiol are comparable.

An enterohepatic cycling is strongly suggested by data in humans (4) and reported for (24R)-hydroxycalcidiol in rats (30). Enterohepatic cycling related maxima are also observed, however, after iv administration. Moreover, this explanation is unlikely in view of the time at which the maximum was observed. For the same reason, involvement of rectal absorption can be excluded. Thus, binding by intestinal cells and (partial) uptake via the lymph system are still plausible explanations.

To estimate the fraction of absorbed (24R)-hydroxycalcidiol, that participates in one of the above hypothetical processes, the difference between the area under the total serum concentration vs time curve $\left(\mathrm{AUC}_{1}\right)$ (tab. 1) and the area under the curve without the second maximum $\left(\mathrm{AUC}_{2}\right)$ was calculated. Based upon this difference, $3 \%$ of measured (24R)-hydroxycalcidiol as estimated from $\left(\mathrm{AUC}_{1}-\mathrm{AUC}_{2}\right) / \mathrm{AUC}_{1}$, appeared to be involved.

We (5) found earlier that iv administration of $25 \mu \mathrm{g}$ of (24R)-hydroxycalcidiol resulted in an AUC of 1374 $\mathrm{nmol} \cdot \mathrm{h} / \mathrm{l}$. Assuming linear pharmacokinetics, this will mean that iv administration of $100 \mu \mathrm{g}$ of $(24 R)$ hydroxycalcidiol will result in an AUC of 5496 $\mathrm{nmol} \cdot \mathrm{h} / \mathrm{l}$ and that the bioavailability of (24R)-hydroxycalcidiol after an oral dose of $100 \mu \mathrm{g}$ is $72 \%$. This estimate agrees well with a bioavailability of about $70 \%$, as determined earlier by us (5).

The significantly higher initial basal concentration and production rate of ( $24 R$ )-hydroxycalcidiol in subject 3 are at least in part explained by the higher plasma concentration of calcidiol, the metabolic precursor of (24R)-hydroxycalcidiol. In this subject, (24R)-hydroxycalcidiol was produced at a higher rate from calcidiol, as reflected in the PR/[calcidiol] ratio which was increased 4-fold (tab. 2). This provides an explanation for the elevated basal concentration.

The production rate of $1.3 \pm 0.4 \mu \mathrm{g} / \mathrm{day}$ is comparable to the production rate of calcitriol (31). The much lower plasma concentration of calcitriol is due to its higher clearance as estimated from reported data (31). 
In the calcium-supplemented subjects, the clearance and production rate of $(24 R)$-hydroxycalcidiol were unchanged, implying that clearance and production rate of this metabolite are not affected by calcium supplementation in these subjects. The significantly lower AUC will mean that the bioavailability of oral (24R)-hydroxycalcidiol is decreased under conditions of calcium supplementation, possibly due to:

a) decreased (active) uptake of the metabolite;

b) more extensive metabolism of (24R)-hydroxycalcidiol by intestinal cells due to an effect of the calcium supplementation on the activity of the metabolizing enzymes; and

c) an effect of calcium supplementation on the receptor of calcitriol known to have some affinity for (24R)-hydroxycalcidiol (30).

Since calcium supplementation would result in raised serum calcidiol (32), the observed decrease of calcidiol represents a seasonal effect. Because calcitriol does not show a clear seasonal variation during January March (33), the observed decrease of calcitriol was at least in part due to calcium supplementation, which is known to depress calcitriol (32).

In the patients with primary hyperparathyroidism, basal concentration at month 9 was significantly higher than its initial value. This was possibly due to a significant seasonal increase of calcidiol (tab. 2) $(P<0.01)$ at the end of the study (May-July). The reason for the significant change of half-time remains to be clarified.

The low production rate in patients with primary hyperparathyroidism was in part due to the lower serum concentration of calcidiol (tab. 2). The PR/ [calcidiol] ratio was 5-10 fold lower in these patients, accounting for the lower serum concentration of (24R)-hydroxycalcidiol. The production rate of (24R)-hydroxycalcidiol was lower in these patients despite significantly higher serum concentrations of calcitriol, which are known to stimulate production of (24R)-hydroxycalcidiol $(7-11)$.

The low plasma concentrations of (24R)-hydroxycalcidiol and the high plasma concentrations of calcitriol in patients with primary hyperparathyroidism were in line with

a) inhibition of the renal 24-hydroxylase activity by parathyroid hormone (parathyrin) $(6-8)$ and b) the stimulation of renal $1 \alpha$-hydroxylase by parathyroid hormone (parathyrin) (34).

The strong positive correlation between plasma concentrations of (24R)-hydroxycalcidiol and calcidiol is consistent with earlier studies of our group $(33,35)$. In patients with primary hyperparathyroidism, the regression line was displaced to the right, implicating a threshold concentration of about $15 \mathrm{nmol} / \mathrm{l}$ above which (24R)-hydroxycalcidiol is produced from calcidiol. In healthy subjects this concentration may be close to $0(33,35)$. The threshold concentration explained the significantly lower PR/[calcidiol] ratios (tab. 2) and serum concentrations of (24R)-hydroxycalcidiol (tab. 2) in the patients with primary hyperparathyroidism.

Though the observed depression of the production rate is not clinically relevant, it may reflect physiologically relevant changes in vitamin $\mathrm{D}_{3}$ metabolism.

In subject 5, an acute and large elevation of serum calcitriol (tab. 3) was seen. The values found for the quality control samples did not parallel this change. Moreover, the observed acute elevation cannot be attributed to diurnal variation, which is less than $20 \%$ (36), or to changes in dietary intake of calcium and/ or phosphate, which cause smaller changes of calcitriol (37). Serum calcium, phosphate and parathyroid hormone (parathyrin) were not markedly affected in this subject. A smaller but marked rise of serum calcitriol was also observed previously by us in other subjects (5). The reasons for these changes of serum calcitriol remains to be clarified.

Exogenous (24R)-hydroxycalcidiol had no effect on the other quantities of calcium metabolism studied.

In conclusion,

a) exogenous (24R)-hydroxycalcidiol has no clear effect on calcium and vitamin D metabolism,

b) clearance and production rate of (24R)-hydroxycalcidiol are not affected by calcium supplementation,

c) bioavailability is lower in the calcium-supplemented state and

d) in patients with primary hyperparathyroidism the basal serum concentration of (24R)-hydroxycalcidiol is significantly decreased, due primarily to a threshold concentration of about $15 \mathrm{nmol} / \mathrm{l}$ for synthesis of (24R)-hydroxycalcidiol, which is reflected in a significantly lower PR/[calcidiol] ratio. 


\section{References}

1. Brommage, R. \& DeLuca, H. F. (1985) Evidence that 1,25 Dihydroxyvitamin $D_{3}$ is the Physiologically Active Metabolite of Vitamin $D_{3}$. Endocrinol. Rev. 6, 491-511.

2. Mason, R. S., Lissner, D., Posen, S. \& Norman, A. W. (1980) Blood Concentration of Dihydroxylated Vitamin D Metabolites after an Oral Dose. Br. Med. J. 280, 449-450.

3. Kanis, J. A., Taylor, C. M., Douglas, D. L., Cundy, T. \& Russell, R. G. G. (1981) Effects of 24,25-Dihydroxy-Vitamin $D_{3}$ on its Plasma Level in Man. Metab. Bone. Dis. Rel. Res. 3, 155-158.

4. Kumar, R., Wiesner, R., Scott, M. \& Go, V. L. W. (1982) Physiology of 24,25-Dihydroxyvitamin $\mathrm{D}_{3}$ in Normal Human Subjects. Am. J. Physiol. (Endocrinol. Metab.) 243, E370-E374.

5. Jongen, M., Van der Vijgh, W. J. F., Netelenbos, J. C., Postma, G. J. \& Lips, P. (1989) Pharmacokinetics of 24,25Dihydroxyvitamin $D_{3}$ in Humans. Hormone Metab. Res. $21,577-580$

6. Armbrecht, H. J., Wongsurawat, N., Zenser, T. V. \& Davis, B. B. (1982) Differential Effect of Parathyroid Hormone on the Renal 1,25-Dihydroxyvitamin $D_{3}$ and 24,25-Dihydroxyvitamin $\mathrm{D}_{3}$ Production of Young and Adult Rats. Endocrinology 111, 1339-1344.

7. Tanaka, Y. \& DeLuca, H. F. (1984) Rat Renal 25-Hydroxyvitamin $\mathrm{D}_{3}$ 1- and 24-Hydroxylases: Their In Vivo Regulation. Am. J. Physiol. (Endocrinol. Metab.) 246, E168E173.

8. Armbrecht, H. J., Wongsurawat, N., Zenser, T. \& Davis, B. B. (1984) Effect of PTH and $1,25(\mathrm{OH})_{2} \mathrm{D}_{3}$ on Renal $25(\mathrm{OH}) \mathrm{D}_{3}$ Metabolism, Adenylate Cyclase, and Protein Kinase. Am. J. Physiol. (Endocrinol. Metab. 9) 246, E102E107.

9. Halloran, B. P. \& Castro, M. E. (1989) Vitamin D Kinetics in Vivo: Effect of 1,25-Dihydroxyvitamin D Administration. Am J. Physiol. (Endocrinol. Metab. 9) 256, E686E691.

10. Armbrecht, H. J., Zenser, T. \& Davis, B. B. (1982) Modulation of Renal Production of 24,25-Dihydroxyvitamin $\mathrm{D}_{3}$ in Young and Adult Rats by Dietary Calcium, Phosphorus, and 1,25-Dihydroxyvitamin $\mathrm{D}_{3}$. Endocrinology $110,1983-$ 1988.

11. Armbrecht, H. J., Wongsurawat, N., Zenser, T. \& Davis, B. B. (1983) In Vitro Modulation of Renal 25-Hydroxyvitamin $D_{3}$ Metabolism by Vitamin $D_{3}$ Metabolites and Calcium. Arch. Biochem. Biophys. 220, 52-59.

12. Armbrecht, H. J., Forte, L. R. \& Halloran, B. P. (1984) Effect of Age and Dietary Calcium on Renal 25(OH)D Metabolism, Serum 1,25(OH $)_{2}$ D, and PTH. Am. J. Physiol. (Endocrinol. Metab. 9) 246, E266-E270.

13. Vieth, R., Fraser, D. \& Kooh, S. W. (1987) Low Dietary Calcium Reduces 25-Hydroxycholecalciferol in Plasma of Rats. J. Nutr. 117, 914-918.

14. Netelenbos, J. C., Asscheman, H., Lips, P., Van der Vijgh, W. J. F., Jongen, M. J. M., Van Ginkel, F. \& Hackeng, W. H. L. (1986) Absence of Effect of 24,25-Dihydroxyvitamin $\mathrm{D}_{3}$ in Primary Hyperparathyroidism. J. Clin. Endocrinol. Metab. 63, 246-248.

15. Jongen, M. J. M., Van der Vijgh, W. J. F., Willems, H. J. J., Netelenbos, J. C. \& Lips, P. (1981) Simultaneous Determination of 25-Hydroxyvitamin D, 24,25-Dihydroxyvitamin D, and 1,25-Dihydroxyvitamin D in Plasma or Serum. Clin. Chem. 27, 1757-1760.

16. Hackeng, W. H. L., Lips, P., Netelenbos, J. C. \& Lips, C. J. M. (1986) Clinical Implications of Estimation of Intact Parathyroid Hormone (PTH) Versus Total Immunoreactive PTH in Normal Subjects and Hyperparathyroid Patients. J. Clin. Endocrinol. Metab. 63, 447-543.
17. Bouillon, R., Van Baelen, H. \& De Moor, P. (1977) The Measurement of the Vitamin D Binding Protein in Human Serum. J. Clin. Endocrinol. Metab. 45, 225-233.

18. Metzler, C. M. \& Weiner, D. L. PCNONLIN. Non Linear Estimation Program Version V02-F, 1986. Statistical Consultants Inc., Lexington, Kentucky.

19. Gibaldi, M. \& Perrier, D. (1982) Appendix D. Estimation of Areas. In: Drug and Pharmaceutical Sciences, Vol. 15, Pharmacokinetics, pp. 445-449, 2nd ed. New York: Marcel Dekker.

20. Ritschel, W. A. (1976) Pharmacokinetics of Single Dose Administration. In: Handbook of Basic Pharmacokinetics, 1st Ed. pp. 213-217, Drug Intelligence Publ., Hamilton.

21. Pedersen, J. I., Shobaki, H. H., Holmberg, I., Bergseth, S. \& Björkhem, I. (1983) 25-Hydroxyvitamin $D_{3}$-24-hydroxylase in Rat Kidney Mitochondria. J. Biol. Chem. 258, $742-746$.

22. Matsumoto, T., Kawanobe, Y. \& Ogata, E. (1985) Regulation of 24,25 -Dihydroxyvitamin D-3 Production by $1,25-$ Dihydroxyvitamin D-3 and Synthetic Human Parathyroid Fragment $1-34$ in a Cloned Monkey Kidney Cell Line (JTC-12). Biochim. Biophys. Acta 845, 358-365.

23. Knutson, J. C. \& DeLuca, H. F. (1974) 25-Hydroxyvitamin D3-24-hydroxylase. Subcellular Location and Properties. Biochemistry 13, 1543-1547.

24. Vieth, R. \& Fraser, D. (1979) Kinetic Behavior of 25Hydroxyvitamin D-1-hydroxylase and 24-Hydroxylase in Rat Kidney Mitochondria. J. Biol. Chem. 254, 1245512460.

25. Gibaldi, M. \& Perrier, D. (1982) Multiple Dosing. In: Drug and Pharmaceutical Sciences, Vol. 15, Pharmacokinetics, p. 139. 2nd Ed. New York: Marcel Dekker.

26. Jarnagin, K., Zeng, S-Y., Phelps, M. \& DeLuca, H. F. (1985) Metabolism and Pharmacokinetics of 24,25-dihydroxyvitamin $D_{3}$ in the Vitamin $D_{3}$ Replete Rat. J. Biol. Chem. 260, 13625-13630.

27. Wilhelm, F., Ross, F. P. \& Norman, A. W. (1986) Specific Binding of 24R,25-Dihydroxyvitamin $\mathrm{D}_{3}$ to Chick Intestinal Mucosa is an Allosteric Effector of 1,25-Dihydroxyvitamin $\mathrm{D}_{3}$ Binding. Arch. Biochem. Biophys. 249, 88-94.

28. Von Westesen, K., Gerke, H. \& Fuhrer, C. (1986) Die Bedeutung der lymphatischen Absorption für perorale Aufnahme von Arzneimittelstoffen. Pharm. Ind. 48, 14191426.

29. Okano, T., Masuda, S., Ishinine, M., Murai, J., Yamamoto, Y. \& Kobayashi, T. (1983) Existence of Vitamin $\mathrm{D}_{3}$ and 25Hydroxyvitamin $\mathrm{D}_{3}$ in Rat Lymph. Chem. Pharm. Bull. 31 , 3233-3241.

30. Kumar, R., Nagubandi, S. \& Londowski, J. M. (1980) The Enterohepatic Physiology of 24,25-Dihydroxyvitamin $\mathrm{D}_{3}$. J. Lab. Clin. Invest. 96, 278-284.

31. Insogna, K. L., Broadus, A. E., Dreyer, B. E., Ellison, A. F. \& G. Gertner, J. M. (1985) Elevated Production Rate of 1,25-Dihydroxyvitamin $\mathrm{D}$ in Patients with Absorptive $\mathrm{Hy}$ percalciuria. J. Clin. Endocrinol. Metab. 61, 490-495.

32. Berlin, T. \& Bjorkhem, I. (1988) Effect of Calcium Intake on Serum Levels of 25 -Hydroxyvitamin $\mathrm{D}_{3}$. Clin. Invest. $18,52-55$.

33. Netelenbos, J. C., Jongen, M. J. M., Van der Vijgh, W. J. F., Lips, P. \& Van Ginkel, F. C. (1985) Vitamin D Status in Urinary Calcium Stone Formation. Arch. Intern. Med. $145,681-684$.

34. Fraser, D. R. \& Kodicek, E. (1973) Regulation of 25Hydroxycholecalciferol-1-hydroxylase Activity in Kidney by Parathyroid Hormone. Nature 241, 163-166.

35. Lips, P., Netelenbos, J. C., Jongen, M. J. M., Van Ginkel, F. C., Althuis, A. L., Van Schaik, C. L., Van der Vijgh, W. 
J. F., Vermeiden, J. P. W. \& Van der Meer, C. (1982) Histomorphometric Profile and Vitamin D Status in Patients with Femoral Neck Fracture. Metab. Bone Dis. Rel. Res. 4, 85-93.

36. Halloran, B. P., Portale, A. A., Castro, C., Morris, R. C. \& Goldsmith, R. S. (1985) Serum Concentration of 1,25Dihydroxyvitamin D in the Human: Diurnal Variation. J. Clin. Endocrinol. Metab. 60, 1104-1110.
37. Portale, A. A., Halloran, B. P., Murphy, M. M. \& Morris, R. C. (19.86) Oral Intake of Phosphorus can Determine the Serum Concentration of 1,25-Dihydroxyvitamin $D$ by $\mathrm{De}$ termining its Production Rate in Humans. J. Clin. Invest. $77,7-12$.

W. J. F. van der Vijgh Clinical Research Laboratory

Department of Internal Medicine Free University Hospital

De Boelelaan 1117

NL-1081 HV Amsterdam

The Netherlands 